\title{
Effect of Amino Acids and Purine Bases on Thiamine Synthesis by Escherichia coli ${ }^{1}$
}

\author{
Akio Iwashima, Takashi Kawasaki, Miyoko NaKamura \\ AND Yoshitsugu Nose ${ }^{2}$ \\ Biochemical Institute, Kyoto Prefectural University of Medicine, \\ Kawaramachi, Kyoto (Post No.602)
}

(Received December 11, 1967)

\begin{abstract}
Phenylalanine and histidine, out of several amino acids tested by the addition to the growth medium of Escherichia coli, showed stimulatory effects on thiamine production by the cells. In order to know the mechanism of phenylalanine action, it was compared with the adenine effect in which adenine added to the growth medium caused a decrease in thiamine production of $E$. coli accompanying with the increase of thiamine synthesizing activity from hydroxymethylpyrimidine and thiazole. Phenylalanine had also a similar elevating effect on thiamine synthesizing activity from hydroxymethylpyrimidine and thiazole in spite of the increase in cellular thiamine contents. The phenylalanine effect could be abolished by a simultaneous thiazole addition at a physiological concentration for the organism in contrast with the adenine effect, which was arrested by hydroxymethylpyrimidine addition. The phenylalanine effect is supposed to be concerned with the synthesis of thiazole moiety of thiamine. The regulation of thiamine biosynthesis in E. coli was also discussed.
\end{abstract}

Recent several isotopic studies for clarifying the precursors of pyrimidine and thiazole moieties of thiamine have revealed that some amino acids as well as formate and acetate effectively incorporated into the thiamine molecule in several organisms (1-7). However, these active compounds except for sulfur-containing amino acids had no appreciable stimulatory effects on de novo synthesis of thiamine in growing, or resting cells of $E$. coli (8). This finding is well understandable from the observations that thiamine biosynthesis is regulated by repression-derepression mechanism in Aerobacter aerogenes (9), in Salmonella typhimurium (10) and $E$. coli (14). In these reports thiamine added to the growth medium of the test organisms caused repression in thiamine synthesis, while adenosine or adenine in the growth medium led to the derepression of thiamine synthesis and to the

\footnotetext{
${ }^{1}$ Following abbreviations are used: hydroxymethylpyrimidine, 2-methyl-4-amino-5-hydroxy。 methylpyrimidine; thiazole, 4 -methyl- $5-\beta$-hydroxyethylthiazole.

2 岩島昭夫, 川崎 尚, 中村美代子, 能勢善嗣。
} 
lowering of the cellular thiamine contents.

The present paper deals with a stimulatory effect of some aromatic amino acids, especially phenylalanine, on thiamine production of $E$. coli and elevation of thiamine synthesis from hydroxymethylpyrimidine and thiazole by the washed cell suspensions of the organism grown in the medium supplemented with phenylalanine. The effect of adenine was also investigated.

\section{EXPERIMENTAL}

\section{Organism and Culture Media}

A wild strain of E. coli ATCC 9637 was used for this work. The basal medium used was that of Davis and Mingioli (11). The inoculum was grown overnight at $37^{\circ}$ in $10 \mathrm{ml}$ of the basal medium.

\section{Chemicals}

Hydroxymethylpyrimidine and thiazole were kindly supplied by Dr. S. Yurugi, Takeda Chemical Industries, Osaka. Amino acids used are all L-form and obtained from commercial sources. Adenine hydrochloride and other purine and pyrimidine bases are the products of Kokoku Pulp Co., Ltd., Tokyo. Takadiastase was purchased from Sankyo Co., Ltd., Tokyo.

\section{Growth of E. coli in Liquid Media}

One drop of the inoculum was inoculated in $25 \mathrm{ml}$ of the basal medium with or without the supplements indicated, followed by incubation for 17-18 hours at $37^{\circ}$ with constant shaking. After incubation, each $5 \mathrm{ml}$ of the cultures was used for growth measurement turbidimetrically, and was calculated to the dry weight of the cells. The cells in the remaining cultures were harvested by centrifugation, washed with a saline solution and resuspended in $5 \mathrm{ml}$ of $0.1 M$ acetate buffer $(\mathrm{pH}$ 4.1). It was used for thiamine assay.

\section{Thiamine Assay}

Thiamine in the cells was extracted by heating for 15 minutes at $85^{\circ}$ in a water bath. This was followed by incubation with Takadiastase at $45^{\circ}$ to convert thiamine phosphates into thiamine. The enzyme reaction was stopped by adding $10 \%$ metaphosphoric acid and centrifuged to remove denatured protein. Thiamine in the supernatant was determined fluorometrically by the thiochrome method after adsorption on permutite using a Shimazu fluorometer (12).

5. Thiamine Synthesis from Hydroxymethylpyrimidine and Thiazole by Washed Cell Suspensions

Washed cell suspensions of $E$. coli were prepared as follows: one milliliter of the inoculum was inoculated in $200 \mathrm{ml}$ of the basal medium with or without the supplements. After incubation for 17 hours at $37^{\circ}$ with constant shaking, the cells were harvested at stationary phase by centrifugation, washed once with sterile saline solution and resuspended in 3 to $5 \mathrm{ml}$ of sterile saline to obtain a cell suspension of $15-20 \mathrm{mg}$ dry weight per $\mathrm{ml}$. The reaction mixture consisted of $20 \mathrm{mM}$ Tris-maleate buffer ( $\mathrm{pH} 7.0$ ), each $10 \mu M$ hydroxymethylpyrimidine $(13.9 \mu \mathrm{g})$ and thiazole $(14.3 \mu \mathrm{g}), 0.2 \%$ glucose, $0.9 \% \mathrm{NaCl}$ and $1 \mathrm{ml}$ of the washed cell suspension in a total volume of $10 \mathrm{ml}$. After incubation for 1 hour at $37^{\circ}$ with constant 
shaking, an aliquot $(8 \mathrm{ml})$ was pipetted into a centrifuge tube and the $\mathrm{pH}$ was adjusted to 4.5 with $N \mathrm{HCl}$. Further procedure was followed by the method for thiamine assay described above. The amount of thiamine formed from hydroxymethylpyrimidine and thiazole were calculated by subtracting initial contents in the cells from total amounts of thiamine detected.

\section{Results}

\section{Effect of Phenylalanine and Histidine in the Growth Medium on Cellular} Thiamine Contents

Several aliphatic amino acids except for sulfur-containing ones failed to increase thiamine content per unit weight of the cells. However, phenylalanine and histidine, among the aromatic and heterocyclic amino acids tested at the concentrations indicated, enhanced cellular thiamine contents (Table 1). The thiamine produced in the cultures was found in the cells, but scarcely detected in the medium.

TABLE 1

Effects of Aromatic and Heterocyclic Amino Acids Added to the Growth Medium on Thiamine Contents of E. coli

\begin{tabular}{|c|c|c|c|c|}
\hline \multirow{2}{*}{$\begin{array}{l}\text { Addition } \\
\text { to medium }\end{array}$} & \multirow{2}{*}{$\begin{array}{l}\text { Cells } \\
\text { produced }\end{array}$} & \multicolumn{2}{|c|}{ Amount of thiamine } & \multirow{2}{*}{ Ratio } \\
\hline & & Total & Per mg cells & \\
\hline$M$ & $m g$ & \multicolumn{2}{|c|}{ mpg } & per cent \\
\hline None & 16.9 & 475 & 28.1 & 100.0 \\
\hline Tryptophan $\left(1 \times 10^{-2}\right)$ & 18.3 & 400 & 21.9 & 78.0 \\
\hline Phenylalanine $\left(1 \times 10^{-2}\right)$ & 16.0 & 725 & 45.3 & 161.1 \\
\hline Tyrosine $\left(1 \times 10^{-2}\right)$ & 20.0 & 550 & 27.5 & 97.9 \\
\hline Histidine $\left(1 \times 10^{-3}\right)$ & 13.6 & 500 & 36.8 & 130.9 \\
\hline Proline $\left(1 \times 10^{-2}\right)$ & 26.8 & 475 & 17.7 & 62.9 \\
\hline
\end{tabular}

The optimal concentrations of phenylalanine and histidine in the reaction mixtures were 10 and $1 \mathrm{~m} M$, respectively and $10 \mathrm{~m} M$ histidine inhibited the growth as shown in Table 2. The phenylalanine effect was a little higher than that of histidine and the cellular thiamine content was one and a half or twice as much as that of the non-supplemented.

TABLE 2

Effects of Concentrations of Phenylalanine and Histidine on Thiamine Contents in the Cells

\begin{tabular}{|c|c|c|c|c|}
\hline \multirow{2}{*}{$\begin{array}{l}\text { Addition } \\
\text { to medium }\end{array}$} & \multirow{2}{*}{$\begin{array}{l}\text { Cells } \\
\text { produced }\end{array}$} & \multicolumn{2}{|c|}{ Amount of thiamine } & \multirow{2}{*}{ Ratio } \\
\hline & & Total & Per mg cells & \\
\hline$M$ & $m g$ & \multicolumn{2}{|c|}{$m \mu g$} & per cent \\
\hline None & 17.1 & 525 & 30.7 & 100.0 \\
\hline Phenylalanine $\left(1 \times 10^{-3}\right)$ & 17.6 & 550 & 31.2 & 101.6 \\
\hline Phenylalanine $\left(1 \times 10^{-2}\right)$ & 17.1 & 800 & 46.8 & 152.3 \\
\hline Phenylalanine $\left(2 \times 10^{-2}\right)$ & 10.1 & 375 & 37.1 & 120.8 \\
\hline Histidine $\left(1 \times 10^{-4}\right)$ & 17.1 & 525 & 30.7 & 100.0 \\
\hline Histidine $\left(1 \times 10^{-3}\right)$ & 15.9 & 575 & 36.2 & 117.9 \\
\hline Histidine $\left(1 \times 10^{-2}\right)$ & No growth & & & \\
\hline
\end{tabular}


The additional effects of various amino acids at the concentrations indicated in the presence of $10 \mathrm{~m} M$ phenylalanine were given in Table 3. Except for methionine there was no increase in thiamine contents in all the cases.

TABLE 3

Additional Effects of Various Amino Acids on Thiamine Contents in the Presence of Phenylalanine

\begin{tabular}{cccc}
\hline \multirow{2}{*}{$\begin{array}{c}\text { Addition } \\
\text { to medium }\end{array}$} & $\begin{array}{c}\text { Cells } \\
\text { produced }\end{array}$ & \multicolumn{2}{c}{ Amount of thiamine } \\
\cline { 3 - 4 }$M$ & $m g$ & Potal \\
\hline Phenylalanine $\left(1 \times 10^{-2}\right)$ & 18.3 & 1,000 & $m \mu g$ \\
+ Glycine $\left(1 \times 10^{-3}\right)$ & 19.4 & 1,050 & 54.7 \\
+ Alanine $\left(1 \times 10^{-3}\right)$ & 19.9 & 1,000 & 54.2 \\
+ Valine $\left(1 \times 10^{-3}\right)$ & 18.5 & 850 & 51.5 \\
+ Leucine $\left(1 \times 10^{-3}\right)$ & 18.4 & 650 & 45.9 \\
+ Isoleucine $\left(1 \times 10^{-3}\right)$ & 18.3 & 900 & 35.3 \\
+ Serine $\left(1 \times 10^{-3}\right)$ & 19.0 & 1,000 & 59.2 \\
+ Threonine $\left(1 \times 10^{-3}\right)$ & 20.2 & 1,100 & 54.6 \\
+ Cystine $\left(1 \times 10^{-3}\right)$ & 12.0 & 200 & 16.7 \\
+ Methionine $\left(1 \times 10^{-3}\right)$ & 18.5 & 1,500 & 81.1 \\
+ Aspartic ac. $\left(1 \times 10^{-3}\right)$ & 19.4 & 1,100 & 56.7 \\
+ Glutamic ac. $\left(1 \times 10^{-3}\right)$ & 19.4 & 875 & 45.1 \\
+ Lysine $\left(1 \times 10^{-3}\right)$ & 17.8 & 875 & 49.2 \\
\hline
\end{tabular}

2. Effects of Purine and Pyrimidine Bases in the Growth Medium on Cellular Thiamine Contents

Since adenosine lowered cellular thiamine contents in A. aerogenes (9), and $S$. typhimurium (10), the same tendency was expected in E. coli. The effects of several purine and pyrimidine bases added to the mixtures at $1 \mathrm{~m} M$ concentrations were therefore examined. As is shown in Table 4, adenine and inosine effectively reduced the thiamine contents in the cells, while adenosine and pyrimidine bases showed no effects at $1 \mathrm{~m} M$ concentrations. The effects of hydroxymethylpyrimidine and thiazole added to the mixture at several concentrations were also investigated.

TABLE 4

Effects of Purines and Pyrimidines on Thiamine Contents

\begin{tabular}{|c|c|c|c|}
\hline \multirow{2}{*}{$\begin{array}{l}\text { Addition } \\
\text { to medium }\end{array}$} & \multirow{2}{*}{$\begin{array}{l}\text { Cells } \\
\text { produced }\end{array}$} & \multicolumn{2}{|c|}{ Amount of thiamine } \\
\hline & & Total & Per mg cells \\
\hline $1 \times 10^{-3} \mathrm{M}$ & $m g$ & \multicolumn{2}{|c|}{$m \mu g$} \\
\hline None & 17.3 & 475 & 27.5 \\
\hline Adenine & 17.0 & 275 & 16.2 \\
\hline Guanine & 28.8 & 600 & 20.8 \\
\hline Hypoxanthine & 17.5 & 350 & $20.0(15.9)^{a}$ \\
\hline Adenosine & 10.1 & 400 & $39.6(19.6)^{a}$ \\
\hline Inosine & 16.6 & 150 & $9.0(5.1)^{a}$ \\
\hline Aminoimidazolecarboxyamide & 17.7 & 350 & $19.8(8.6)^{a}$ \\
\hline AMP & 18.9 & 450 & 23.8 \\
\hline Cytosine & 17.1 & 450 & 26.3 \\
\hline Uracil & 17.6 & 475 & 27.0 \\
\hline Thymine & 17.0 & 475 & 27.9 \\
\hline
\end{tabular}

a The value after addition of $10^{-2} \mathrm{M}$. 
TABLE 5

Effects of Hydroxymethylpyrimidine and Thiazole Added to the Medium on Thiamine Contents

\begin{tabular}{lccc}
\hline \multirow{2}{*}{$\begin{array}{c}\text { Addition } \\
\text { to medium }\end{array}$} & \multirow{2}{*}{$\begin{array}{c}\text { Cells } \\
\text { produced }\end{array}$} & \multicolumn{2}{c}{ Amount of thiamine } \\
\cline { 3 - 4 } & \multicolumn{2}{c}{ Total } & Per mg cells \\
\hline None & $m g$ & 475 & $m \mu g$ \\
Hydroxymethylpyrimidine $\left(1 \times 10^{-7}\right)$ & 16.8 & 575 & 28.3 \\
Hydroxymethylpyrimidine $\left(1 \times 10^{-6}\right)$ & 16.9 & 600 & 34.0 \\
Hydroxymethylpyrimidine $\left(1 \times 10^{-5}\right)$ & 16.9 & 650 & 35.5 \\
Hydroxymethylpyrimidine $\left(1 \times 10^{-4}\right)$ & 16.8 & 625 & 38.7 \\
Thiazole $\left(1 \times 10^{-7}\right)$ & 17.9 & 450 & 26.5 \\
Thiazole $\left(1 \times 10^{-6}\right)$ & 17.3 & 450 & 26.0 \\
Thiazole $\left(1 \times 10^{-5}\right)$ & 17.3 & 475 & 27.5 \\
Thiazole $\left(1 \times 10^{-4}\right)$ & 17.3 & 500 & 28.9 \\
\hline
\end{tabular}

As is shown in Table $5,0.1$ to $100 \mu M$ hydroxymethylpyrimidine in the mixture elevated cellular thiamine contents to the same extents, while the same amounts of thiazole had no effect. It is of interest in regulation of thiamine synthesis in $E$. coli as later discussed in this paper that only the pyrimidine moiety of thiamine, but not thiazole, stimulated thiamine production though the presence of both compounds elevated much more thiamine content than with hydroxymethylpyrimidine alone. On the other hand, the adenosine effect in A. aerogenes is thought to be due to the inhibition of hydroxymethylpyrimidine synthesis leading to the lowered thiamine contents in the cells (9). The addition of hydroxymethylpyrimidine to the medium seems to overcome this inhibition, causing cellular thiamine synthesis in the cells. That this is also the case in $E$. coli, is shown in Table 6, in which $0.1 \mu \mathrm{M}$ hydroxymethylpyrimidine added to the mixture with adenine brought about the elevated thiamine content to the normal level but it was not the case with thiazole, even at 100 times concentration.

TABLE 6

Abolishment by Hydroxymethylpyrimidine of Adenine Effect on Cellular Thiamine Contents

\begin{tabular}{lc}
\hline \multicolumn{1}{c}{ Addition to medium } & Thiamine produced \\
\hline \multicolumn{1}{c}{$M$} & $m \mu g / m g$ cells \\
None & 23.7 \\
Adenine $\left(1 \times 10^{-3}\right)$ & 12.7 \\
Adenine+hydroxymethylpyrimidine $\left(1 \times 10^{-8}\right)$ & 12.5 \\
Adenine+hydroxymethylpyrimidine $\left(1 \times 10^{-7}\right)$ & 21.7 \\
Adenine thiazole $\left(1 \times 10^{-7}\right)$ & 14.0 \\
Adenine+thiazole $\left(1 \times 10^{-5}\right)$ & 14.0 \\
\hline
\end{tabular}

\section{Mechanism of Phenylalanine Action}

Since hydroxymethylpyrimidine could overcome the adenine effect of reducing cellular thiamine content, the effects of adding hydroxymethylpyrimidine or thiazole on phenylalanine effect was investigated. As is shown in Table 7, the elevated cellular thiamine contents by phenylalanine were brought back to the control level with $0.1 \mu M$ thiazole, but not with hydroxymethylpyrimidine. This suggests that phenylalanine is concerned somehow with the synthesis of thiazole 
TABLE 7

Effects of Thiazole on Cellular Thiamine Content Elevated by Phenylalanine

\begin{tabular}{cccc}
\hline \hline $\begin{array}{c}\text { Addition } \\
\text { to medium }\end{array}$ & $\begin{array}{c}\text { Cells } \\
\text { produced }\end{array}$ & \multicolumn{2}{c}{ Amount of thiamine } \\
\cline { 3 - 4 }$M$ & $m g$ & Total & per mg cells \\
\hline None & 17.7 & 500 & 28.2 \\
Phenylalanine $\left(1 \times 10^{-2}\right)$ & 17.7 & 1,150 & 65.2 \\
$\quad$ + thiazole $\left(1 \times 10^{-8}\right)$ & 17.6 & 900 & 51.1 \\
+ thiazole $\left(1 \times 10^{-7}\right)$ & 17.6 & 600 & 34.1 \\
+ thiazole $\left(1 \times 10^{-6}\right)$ & 17.6 & 550 & 31.2 \\
+ thiazole $\left(1 \times 10^{-5}\right)$ & 17.7 & 500 & 28.2 \\
+ thiazole $\left(1 \times 10^{-4}\right)$ & 17.7 & 450 & 25.4 \\
+ hydroxymethylpyrimidine $\left(1 \times 10^{-7}\right)$ & 17.8 & 1,150 & 64.6 \\
+ hydroxymethylpyrimidine $\left(1 \times 10^{-4}\right)$ & 17.7 & 1,150 & 65.0 \\
\hline
\end{tabular}

portion of thiamine in analogy to the effect of adenine which inhibits the synthesis of pyrimidine portion. However, phenylalanine had a paradoxical effect compared with that of adenine: phenylalanine increased cellular thiamine contents, whereas adenine reduced them.

4. Thiamine Synthesis from Hydroxymethylpyrimidine and Thiazole by Washed Cell Suspensions of E. coli Grown in a Medium Supplemented with Adenine or Phenylalanine

In order to know more precise action of phenylalanine, thiamine synthesizing activities from hydroxymethylpyrimidine and thiazole by non-growing cell suspensions of $E$. coli grown in a medium supplemented with or without adenine or phenylalanine were compared as described in the Method. The resting cells as well as growing cells of $E$. coli can easily synthesize thiamine from hydroxymethylpyrimidine and thiazole added to the medium in the presence of glucose (13). The stimulation of thiamine synthesis by resting cells of S. typhimurium preincubated with adenosine was also reported (10). As shown in Table 8, it was found that phenylalanine $(5 \mathrm{mM})$ increased the thiamine synthesizing activities from hydroxymethylpyrimidine and thiazole about twice as much as that of the non-supplemented. The degree is a little lower than that detected with adenine. The effect of adenine on stimulation of thiamine synthesis by washed cell suspensions appeared to be due to derepression in thiamine synthesis. Although phenylalanine had an opposite effect to adenine in respect of the cellular thiamine contents, the effect by phenylalanine might be due to derepression in thiamine synthesis. As might be expected from the result of thiazole effect on thiamine contents of the cells, thiazole added

TABLE 8

Thiamine Synthesis from Hydroxymethylpyrimidine and Thiazole by Cell Suspensions of $E$. coli

\begin{tabular}{cccc}
\hline $\begin{array}{c}\text { Addition } \\
\text { in } \\
\text { incubation }\end{array}$ & $\begin{array}{c}\text { Amount of } \\
\text { thiamine } \\
\text { per mg cells }\end{array}$ & $\begin{array}{c}\text { Thiamine } \\
\text { formed }\end{array}$ & $\begin{array}{c}\text { Thiamine } \\
\text { formed } \\
\text { per mg cells }\end{array}$ \\
\hline \multicolumn{1}{c}{$M$} & $m \mu \mathrm{g}$ & $m \mu g$ & $m \mu g$ \\
None & 22.2 & 3,340 & 210 \\
+ adenine $\left(2 \times 10^{-3}\right)$ & 11.1 & 10,200 & 570 \\
+ phenylalanine $\left(5 \times 10^{-3}\right)$ & 34.0 & 6,800 & 400 \\
\hline
\end{tabular}


TABLE 9

Abolishment by Thiazole of Phenylalanine Effect on Elevation of Thiamine Synthesis

\begin{tabular}{|c|c|c|c|}
\hline $\begin{array}{l}\text { Addition } \\
\text { in } \\
\text { incubation }\end{array}$ & $\begin{array}{l}\text { Amount of } \\
\text { thiamine } \\
\text { per mg cells }\end{array}$ & $\begin{array}{l}\text { Thiamine } \\
\text { formed }\end{array}$ & $\begin{array}{l}\text { Thiamine } \\
\text { formed } \\
\text { per mg cells }\end{array}$ \\
\hline$M$ & $m \mu g$ & $m \mu g$ & $m \mu g$ \\
\hline $\begin{array}{l}\text { None } \\
+ \text { phenylalanine }\left(1 \times 10^{-2}\right)\end{array}$ & $\begin{array}{l}15.7 \\
60.0\end{array}$ & $\begin{array}{r}5,100 \\
11,800\end{array}$ & $\begin{array}{r}220 \\
1,000\end{array}$ \\
\hline $\begin{array}{r}+ \text { phenylalanine }\left(1 \times 10^{-2}\right) \\
\text { and thiazole }\left(1 \times 10^{-7}\right)\end{array}$ & 21.9 & 5,950 & 270 \\
\hline $\begin{array}{c}+ \text { phenylalanine }\left(1 \times 10^{-2}\right) \\
\text { and thiazole }\left(1 \times 10^{-6}\right)\end{array}$ & 22.9 & 6,100 & 290 \\
\hline
\end{tabular}

at a physiological concentration for bacterial growth to the medium with phenylalanine, abolished the elevation of thiamine synthesizing activities from hydroxymethylpyrimidine and thiazole by the resting cells (Table 9). This indicates that the derepression in thiamine synthesis induced by phenylalanine was arrested by thiazole.

\section{Discussion}

In the course of study of the effects on thiamine synthesis by E. coli of several amino acids added to the growth medium, we found that phenylalanine as well as histidine specifically elevated cellular thiamine contents. It is well known that sulfur containing amino acids had some stimulatory effect on thiamine synthesis as efficient precursors in the synthesis of the thiazole moiety of thiamine (8). However, it was unexpected that phenylalanine and histidine showed such stimulatory effect on de novo thiamine synthesis as much as or much more than cysteine and methionine, as they do not seem to be precursors of the pyrimidine or thiazole moiety of thiamine. In further experiments, it was shown that the compounds structually similar to phenylalanine such as $\beta$-phenylethylamine and $\beta$-phenylethylalcohol had no effect on thiamine production. From the results obtained in studying the phenylalanine effect compared with that of adenine apart from histidine action which needs to be checked, the elevation by phenylalanine of thiamine contents in the cells accompanied with an increase in thiamine synthesizing activities from hydroxymethylpyrimidine and thiazole by the resting cells preincubated with phenylalanine. In addition, the phenylalanine effect was abolished by simultaneous addition of thiazole at a low concentration $(0.1 \mu M)$ which is physiological for the growth of $E$. coli. These results favour to give an idea that the stimulation of thiamine production by phenylalanine may be due to derepression of thiamine synthesizing enzymes caused by inhibition of thiazole synthesis by the compound in contrast with the conception of adenine. As already mentioned, thiamine synthesis is regulated by the ultimate product in the thiamine synthesis pathway and it is derepressible by adenine which caused reduction of thiamine contents in the cells by inhibiting the synthesis of the pyrimidine moiety of thiamine. The paradoxical effect of phenylalanine on elevating cellular thiamine contents is not fully understandable. However, recalling the data given in Table 5 in which a surplus 
supply of hydroxymethylpyrimidine increases thiamine production in the cells, but not thiazole and also the conception by Moyed (9) that thiazole synthesis is controlled by thiazole itself rather than by the ultimate product, thiamine, it is possible to assume that phenylalanine may compete with an unknown precursor in thiazole synthesis pathway and this competition may reduce a thiazole pool in the cells which leads to derepress thiamine synthesizing system and increase thiamine contents as a result of derepression.

\section{ACKNOWLEDGEMENT}

We wish to thank Dr. A. Fujita for his kind revision and also Dr. S. Yurugi for a gift of hydroxymethylpyrimidine and thiazole. This work was supported by a grant for Scientific Research of the Education Ministry.

\section{REFERENCES}

1. David, S., and Estramareix, B., Biochim. Biophys. Acta, 42, 562 (1960).

2. Goldstein, G. A., and Brown, G. M., Arch. Biochem. Biophys., 103, 449 (1963).

3. Tomlinson, R. V., Biochim. Biophys. Acta, 115, 529 (1966).

4. David, S., Estramareix, B., and Hirshfeld, H., Biochim. Biophys. Acta, 148, 11 (1967).

5. Kumaoka, H., J. Vitaminol., 9, 188 (1963).

6. Johnson, D.B., Howells, D. J., and Goodwin, T. W., Biochem. J., 98, 30 (1966).

7. Tomlinson, R. V., Kuhlman, D. P., Torrence, P. F., and Tieckelman, H., Biochim. Biophys. Acta, 148, 1 (1967).

8. Akagi, M., and Kumaoka, H., J. Vitaminol., 9, 183 (1963).

9. Moyed, H. S., J. Bacteriol., 88, 1024 (1964).

10. Newell, P. C., and Tucker, R. G., Biochem. J., 100, 512 (1966).

11. Davis, B. D., and Mingioli, E. S., J. Bacteriol., 60, 17 (1950).

12. Fujita, A., in S.P. Colowick and N. O. Kaplan (Editors), Methods in Enzymology, II, Academic Press, New York, 1955, p. 622.

13. Nose, Y., Tokuda, Y., Hirabayashi, M., and Iwashima, A., J. Vitaminol., 10, 105 (1964).

14. Kawasaki, T., Iwashima, A., and Nose, Y., unpublished. 